\section{The HIV positive dentist in the United Kingdom - the dilemma of the undiagnosed clinician}

\author{
M. Williams'
}

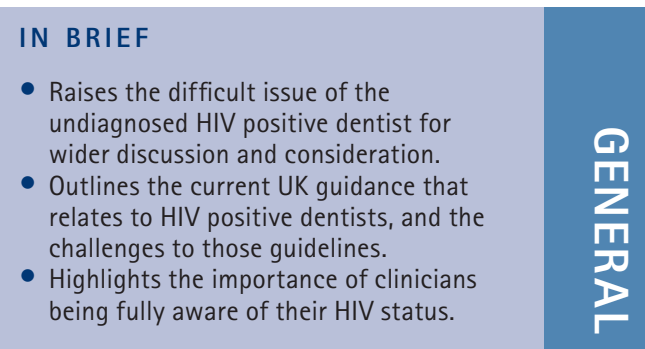

This article considers the position of the HIV positive dentist in the United Kingdom who is unaware of their HIV status, or who at least has had no positive HIV test result. It outlines the current UK guidance that relates to HIV positive dentists, and the challenges to those guidelines. It considers how the behaviour of a practising seropositive dentist who has had no positive test result might be interpreted by regulatory bodies and the courts, and highlights the importance of clinicians being fully aware of their HIV status.

\section{INTRODUCTION}

Dentists in the United Kingdom diagnosed as HIV positive are obliged to cease contemporary clinical practice. This follows advice relating to exposure-prone procedures (EPPs) in dentistry from the United Kingdom Advisory Panel for healthcare workers infected with blood-borne viruses (UKAP). ${ }^{1}$ The subject hinges on the tension surrounding the perceived level of risk of transmission of HIV from the infected dentist to patients. The risk is extremely low, ${ }^{2-5}$ but nevertheless real. ${ }^{6}$ Nine patients have reportedly contracted HIV from infected healthcare workers. ${ }^{7-12}$ Notoriously, six of these were infected by a dentist in Florida (Dr Acer). ${ }^{7}$

The conclusion that Dr Acer infected six patients in his care was based on an epidemiologic and laboratory investigation that failed to identify other documented sources of HIV for these six patients, and found that all six had HIV strains with DNA sequences that closely resembled the dentist's strain. ${ }^{7}$

Neither the precise mode of HIV transmission to these patients, nor the reasons for transmission to multiple patients are known. ${ }^{13}$

Specialist in Oral Surgery, Head of Service, Cambridge University Dental Service, 3 Trumpington Street, Cambridge, CB2 10A

Correspondence to: Dr Mike Williams

Email:mhw39@cam.ac.uk

\section{Refereed Paper}

Accepted 26 January 2011

DOI: $10.1038 /$ sj.bdj.2011.287

${ }^{\circledR}$ British Dental Journal 2011; 210: 375-379
Since the time of Dr Acer, the introduction of highly active anti-retroviral therapy (HAART) has led to a dramatic decline in morbidity and mortality among patients infected with HIV. ${ }^{14}$ In the United Kingdom, HIV/AIDS has been transformed from being a fatal disease to a chronic illness. ${ }^{15}$ Antiretroviral therapy can reduce HIV type 1 viraemia to below the detection limit of ultra sensitive clinical assays (50 copies of HIV-1 RNA/ml). ${ }^{16,17}$ Viral load is the chief predictor of risk of heterosexual transmission of HIV-1 and it is known that transmission is rare among persons with levels of less than 1,500 copies of HIV-1 RNA per millilitre. ${ }^{18}$

Recent studies support the non-transmissibility of the disease from individuals effectively treated with ant-retrovirals. ${ }^{19,20}$ The 2009 Beijing Declaration supports the view that oral healthcare professionals with HIV do not pose a risk of transmission to patients in the dental setting, providing:

- The individual is under ongoing care by a suitably qualified HIV health care professional

- The individual remains aware of his/ her health status and acts appropriately

- Standard infection control is observed

- Scientific evidence related to HIV transmission continues to be reviewed. ${ }^{21}$

Some European countries now allow HIV positive dentists to work. ${ }^{22}$ The current UKAP guidelines are under review, ${ }^{23}$ and may be subject to legal challenge, ${ }^{24}$ and the General Dental Council (GDC) is in the process of reconsidering its view on registrants with HIV. ${ }^{25}$

The identification of healthcare workers with a positive HIV diagnosis has led to multiple patient notification exercises (look back procedures). ${ }^{26-29}$ With the exception of a French orthopaedic surgeon, look back procedures have conspicuously failed to identify any transmission of HIV from an infected healthcare worker to a patient. ${ }^{30-32}$

The low risk of transmission has called into question the value of look-back procedures, which are considered disruptive and expensive, and, it is claimed, should no longer be routinely recommended. ${ }^{27,33,34}$ Since 2003, Department of Health (DoH) guidance has advised that look back procedures take place in rare circumstances only. ${ }^{35}$ Nevertheless, others argue forcefully that look back procedures are important, ${ }^{36}$ and they continue to be set in motion..$^{37,38}$

The 2003 DoH guidance ${ }^{35}$ followed the case of $\mathrm{H}$ (A Healthcare Worker) v Associated Newspapers Ltd, ${ }^{39}$ H's respect for private life, ${ }^{40}$ was set against the right to freedom of expression of the press. ${ }^{41} \mathrm{H}$ also challenged the right of the health authority to undertake a look-back procedure.

In balancing the tension between articles 8 and 10 of the Human Rights Act, the Appeal Court held that there was a public interest in maintaining H's confidentiality, and upheld the injunction against naming 
H or N (The Health Authority). However, the risk of discovery of H's identity was insufficient to continue restriction on disclosure of his specialty (as a dentist), as this was deemed a matter of public interest worthy of debate.

It is known that HIV infectivity is not constant. ${ }^{42}$ Primary infection is 26 times more infectious than asymptomatic infection, and late stage seven times more infectious than asymptomatic infection. High infectiousness associated with primary infection lasts approximately three months after seroconversion, and that associated with late stage lasting approximately 10-19 months before death. ${ }^{42}$ Primary HIV infection defines a brief period after inoculation with HIV that is characterised by intense viraemia, a subsequent immune response, and in the majority of patients, a brief, febrile illness. ${ }^{43}$ The development of severe HIV-1 related disease within the first two years after infection is unusual. ${ }^{43}$

\section{THE UNDIAGNOSED CLINICIAN}

The diagnosis of HIV infection is established by two steps, screening assays and confirmatory assays. ${ }^{44}$ Ninety-seven percent of persons will develop detectable antibodies within the first three months of their infection though in rare cases it can take up to six months. ${ }^{45}$ In the United Kingdom, in 2008, 83,000 people were estimated to be living with HIV, of whom $27 \%$ were unaware of their infection. ${ }^{46}$ In 2008, 7,298 new HIV cases were diagnosed;46 almost a third (32\%) of persons newly diagnosed with HIV was diagnosed late; ${ }^{46}$ and a recent report suggests as many as $40 \%$ of gay men with HIV may be unaware. ${ }^{47}$ It is possible then that an HIV infected dentist might continue to work in the absence of a positive HIV test, unaware of their HIV status, and inevitably without the benefit of HAART.

Previous guidance from the General Dental Council stated that a dentist who is aware of being infected with a blood borne virus or any other transmissible disease or infection which might jeopardise the wellbeing of patients, or who has reason to believe that such infection may be present and takes no action is behaving unethically, and that failure to obtain medical advice which may result in appropriate testing would almost certainly lead to a charge of serious professional misconduct. ${ }^{48}$ This has been superseded by current GDC guidance that requires dental professionals to be familiar with and understand current standards that affect their work, the evidence base that supports those standards, and relevant guidelines issued by organisations other than the GDC. ${ }^{49}$

Department of Health guidance states that a healthcare worker who has any reason to believe that they may have been exposed to infection with HIV, in whatever circumstance, must seek and follow confidential professional advice regarding testing without delay; ${ }^{50}$ that failure to do so may breach the duty of care to patients; and lists examples of how a healthcare worker may become exposed to HIV infection in both social and professional environments. It goes on to place a burden on professional colleagues, knowing of an HIV infected individual practising in a way which places patients at risk, to inform an appropriate person in the healthcare worker's employing authority, or the relevant regulatory body.

Universal and standard infection control procedures are designed to protect healthcare workers and patients, ${ }^{28}$ and are demanded by the 2008 Health and Social Care Act. ${ }^{51}$ Best practice guidance is set out in the HTM 01-05 document ${ }^{52}$ and essential standards will be monitored by the Care Quality Commission ${ }^{53}$ but it is known that compliance in dental practice is sometimes lacking. ${ }^{28,54}$

The undiagnosed clinician would lie at the very least outside the first two caveats of the Beijing Declaration.

\section{THE UNDIAGNOSED CLINICIAN THAT CONTINUES TO WORK}

Dentists that are HIV positive who continue to work potentially face a number of legal challenges. ${ }^{55}$ In the case of actual transmission of HIV from the dentist to patient, the dentist may be liable for inflicting grievous bodily harm contrary to the recklessness provisions of s 20 of the Offences Against the Person Act 1861 (OAPA), unless the patient was fully informed of the risks, and consented to them. The Crown Prosecution Service (CPS) has successfully prosecuted a number of HIV positive individuals following the transmission of HIV through unprotected, consensual intercourse to an unsuspecting partner using these provisions. ${ }^{56}$ Although the criminalisation of
HIV transmission in this way has been criticised, ${ }^{57}$ such prosecutions have been a priority for the CPS. ${ }^{58}$

Guidelines issued by the CPS in 2008 to clarify the law advise that a person can only be convicted of reckless sexual HIV transmission if there is, '...a sustained course of conduct during which the defendant ignores current scientific advice regarding the use of safeguards. ${ }^{59}$ While recognising concerns about discrimination, the guidelines go on to say:

'We will be mindful of any indications that there is a disproportionate impact on any particular group of individuals that we may prosecute ... however, where there is sufficient evidence and it is in the public interest to prosecute, the CPS has a duty to the complainant and to society at large to bring the defendant before the courts...'

An alternative remedy in the event of actual transmission of HIV might be provided by the Control of Substances Hazardous to Health Regulations 2002 (COSHH Regulations). ${ }^{55,60}$

In the absence of actual transmission a challenge may come from individuals claiming injury based on their fear of acquiring AIDS by a potential exposure to an HIV infected person, even though those individuals have not in fact acquired AIDS or HIV infection. ${ }^{61}$

Recklessness involves a conscious risktaking. A person is reckless if, knowing that harm may result from his conduct, he takes that risk, and it is unreasonable for him to take it having regard to the circumstances that he is aware of at the time. ${ }^{62}$ It is no defence for a person to say that he just did not think about a risk that should have been obvious, and which goes beyond mere carelessness ${ }^{63}$ (Caldwell Test ${ }^{64}$ ). What is brought within recklessness is a greater degree of culpability than mere negligence so that the criminal law should intervene. ${ }^{63}$

Could s 20 be used against someone who is not actually aware that they have HIV (ie not medically diagnosed) but who suspects that they may be infected?

It has been argued that in order to be subjectively reckless and aware of the risk to others, actual knowledge of HIV positive status is required. ${ }^{65}$ However, others suggest that recklessness does not require actual knowledge and the individual can be aware of the risk having 
previously engaged in practices that they knew involved a risk of transmission. ${ }^{66,67}$ In a 2004 case, ${ }^{68}$ the defendant (Mr Adaye) pleaded guilty to all charges including one count of reckless transmission. As he pleaded guilty little detail is known about case. However, it would seem that he did not actually know that he had HIV. He had been advised that he was at high risk and advised to take a test, but he did not follow that advice. On what basis was liability imposed?

The broader view of recklessness could be put forward ${ }^{67}$ and indeed Judge David Lynch, presiding in the case suggested in the press that in effect the defendant knew that he might be HIV positive. Criminal liability then is imposed on grounds of knowledge in the 2nd degree, or wilful blindness. ${ }^{69}$

Culpability derives from the fact that the person concerned alerts their mind to the possible risk, but then turns a blind eye. ${ }^{69}$ The concept of wilful blindness is easily applied to HIV. The defendant had good cause to suspect he might be infected, yet closed his mind to the risk by not getting tested, and refused to take advantage of the means of actual knowledge. ${ }^{69}$ In support of this view, wilful blindness may be considered just as morally blameworthy as someone who has actual knowledge. (This seems to be the view of Judge Lynch in Adaye. ${ }^{69}$ ) It is often suggested that confining liability to actual knowledge may operate as a disincentive to testing, and might, it is argued, encourage HIV positive individuals to avoid having medical confirmation to escape liability, ${ }^{69,70}$ although there is no empirical evidence for or against this. ${ }^{69}$ Set against this, the basic principle of fairness requires the accused to be aware of their infective status. Imposition of liability in the absence of knowledge spreads the net of criminal liability very wide, and would mean that anyone who has had unprotected sex and no negative test result could be potentially liable. This then may be regarded as either a necessity to protect vulnerable individuals from the callous indifference of others, or a travesty of natural justice, depending upon your point of view. Certainly, the question would be raised of the sort of previous conduct that would suggest wilful blindness, introducing the potential for prejudicial judgement. ${ }^{69}$ Who would decide what does or does not constitute risk behaviour?
It has been reported, for example, that a small number of HIV positive individuals who present late in the course of infection, have low, unrecognised or unacknowledged risk for HIV. ${ }^{71}$

Even following a positive test result; an individual may not have adequate counselling in terms that they understand, and knowledge about risk of transmission may be in doubt. ${ }^{72}$ Would the General Dental Council expect dentists to be well informed about risks of transmission?

Medical professionals, in line with others with a professional education, have comparatively low death risks compared with the general population..$^{73,74}$ However, it would seem that they do not use their professional knowledge and skills in a way that reduces their own mortality risk. ${ }^{75-78}$

Nevertheless, general principles suggest that a person would be expected to take into account any matters within the knowledge and experience of his peers about which he knows or ought to know. This would apply to the ordinary law of negligence, and also to health and safety law. In 1997 an obstetrician was deregistered by the General Medical Council (GMC) because he delayed being tested for HIV and continued working when he suspected he may have been HIV positive. ${ }^{79}$

The risk of transmission of HIV from an infected patient to a healthcare worker through occupational percutaneous exposure (inoculation injury) is much greater than the risk of transmission from the healthcare worker to the patient, and is estimated at one in $300 .{ }^{80}$

However, the combined risk of contracting HIV infection from the source patient and then transmitting it to another during an exposure-prone procedure is so low as to be considered negligible, and healthcare workers are not required to refrain from performing exposure-prone procedures pending follow-up of occupational exposure to an HIV infected source. ${ }^{50}$

\section{LATE DIAGNOSIS AND TESTING}

Late diagnosis is associated with shortterm mortality, ${ }^{81-83}$ is implicated in onward transmission of infection, ${ }^{84,85}$ and is associated with increased care and management costs. ${ }^{86,87}$ Reasons for late presentation with HIV infection are complex and poorly understood, but certainly include psychosocial factors. ${ }^{88}$ It is recognised that there are missed opportunities for earlier diagnosis, with many patients presenting with advanced disease after initially presenting with HIV related symptoms but with their HIV infection remaining undiagnosed. ${ }^{89}$ Those who are detected late tend to be older, mainly men, heterosexual with stable partners and children. ${ }^{90,91}$

The problem of late diagnosis has led numerous authors to advocate wider HIV testing. ${ }^{92-94}$

The 2008 National guidelines on testing state:

- Patients should be offered and encouraged to accept HIV testing in a wider range of settings than is currently the case

- Patients with specific indicator conditions should be routinely recommended to have an HIV test

- All doctors, nurses and midwives should be able to obtain informed consent for an HIV test in the same way that they currently do for any other medical investigation. ${ }^{95}$

While the benefits of swift diagnosis are generally welcomed, lowering the threshold for testing is viewed with caution by some. ${ }^{96,97}$

Kimberley Bergalis (patient A), ${ }^{98}$ who became the most publicised of Dr Acer's patients infected with HIV, campaigned vociferously for mandatory routine HIV testing of health workers, ${ }^{99}$ giving evidence before the United States Congress. The legislation stalled in the face of strong opposition from organisations representing healthcare professionals. The Centre for Disease Control (CDC) stated that mandatory HIV screening of healthcare workers who performed invasive procedures was not necessary because testing would not further reduce the "negligible risks of transmission'. ${ }^{100}$

Critics of the restrictive proposals promoted in 'Kimberley's law' argued this was a risk prevention policy that not only failed to evaluate the level of risk, but did not distinguish the difference between regulating things or procedures that have no human rights, and regulating people, who do have rights that should not be infringed without serious justification. ${ }^{101}$ These are criticisms that still resonate today.

In the UK, the 2007 Department of Health Guidance ${ }^{102}$ requires healthcare 
workers who are new to the NHS, and who carry out exposure-prone procedures (EPPs) to have additional health clearance checks to demonstrate they are free from infection with hepatitis BV, hepatitis C, HIV and TB. Medical and dental students are required to undergo additional health clearance before being accepted onto their course. The document recognises that one off testing is no guarantee against future infection, but falls back on the professional codes of practice from regulatory bodies, and the ongoing obligation of healthcare workers to seek professional advice (and testing if necessary), if they have been exposed to a serious communicable disease. The new guidelines have been criticised, ${ }^{103}$ and it has been argued that in effect mandatory HIV testing has now been introduced for a large number of health care workers. ${ }^{104}$

\section{CONCLUSION}

HIV is less readily transmitted than Hepatitis B and C viruses, ${ }^{105}$ which also have associated morbidity. Guidance for Healthcare Workers infected with these viruses is set out by the Department of Health, ${ }^{106,107}$ but hepatitis B and hepatitis $\mathrm{C}$ are notifiable diseases. ${ }^{108}$ A notifiable disease is one which a registered medical practitioner is legally bound to report to the relevant authorities, and failure to do so can result in summary conviction and fine. ${ }^{109}$

HIV is not notifiable in the United Kingdom; it has always been thought that any forced breach of confidentiality of HIV positive patients would be regarded as a threat to their interests, and be a deterrent to patients coming forward for treatment, leaving authorities with no effective way of monitoring the disease. This underlines the facts that concern with HIV infection relates not only to the disease itself, but also to the social stigma that surrounds it. ${ }^{109}$

The legal judgements in the reckless transmission cases $^{56}$ place the burden on individuals to behave in a responsible manner, and must also place a burden on governments and legal institutions to behave responsibly, and not out of fear and prejudice. ${ }^{110}$ Any review of current recommendations will seek to protect patients, but also reflect the remote risk of transmission of HIV from an infected dentist, whose infection is controlled by HAART, and who undertakes universal precautions. Where would the undiagnosed individual fit into the scheme of things?

The Secretary General of the United Nations declared in 2006 that:

'Countries should promote, through global and national campaigns, the ideal that each person knows his or her HIV status and has access to AIDS information, counselling and related services, in a social and legal environment that is supportive and safe for confidential testing and voluntary disclosure of HIV status. ${ }^{.11}$

Clearly self-awareness and voluntary testing is to be encouraged in responsible individuals. It is then a matter of protecting these individuals, who themselves have to come to terms with their own HIV/AIDS related problems and anxieties, from unfair, unequal and right-infringing treatment.

1. Health Protection Agency. UK Advisory Panel for healthcare workers infected with bloodborne viruses (UKAP). www.hpa.org.uk/webw/ HPAweb\&tPagectHPAwebAutoListName/Page/12034 $96960618 ? \mathrm{p}=1203496960618$

2. Scully C, Porter S R. Can HIV be transmitted from dental personnel to patients by dentistry? Br Dent $J$ 1993; 175: 381-382.

3. Robinson P, Challacombe S. Transmission of HIV in a dental practice - the facts. Br Dent J 1993; 175: 1993 383-384.

4. Robert $L M$, Chamberland $M E$, Cleveland J L et al. Investigations of patients of healthcare workers infected with HIV: The Centres for Disease Control and Prevention Database. Ann Intern Med 1995; 122: 653-657.

5. Department of Health Publications, Policy and Guidance. Current estimates of the risk of HIV transmission. www.dh.gov.uk/ en/publicationsandstatistics/Publications/ PublicationsPolicyAndGuidance/Browsable/ DH 5354249

6. Tumin W, Bagg J. Achieving balance. Br Dent J 2006; 201: 740-741.

7. Ciesielski C A, Marianos D W, Schochetman G White J J, Jaffe H W. The 1990 Florida Dental Investigation: the press and the science. Ann Intern Med 1994; 121: 886-888.

8. Ou C Y, Ciesielski C A, Myers G et al. Molecular epidemiology of HIV transmission in a dental practice. Science 1992; 256: 1165-1171.

9. Possible transmission of human immunodeficiency virus to a patient during an invasive dental procedure. MMWR Morb Mortal Wkly Rep 1990; 39: 489-493.

10. Lot $F$, Séguier J $C$, Fégueux $S$ et al. Probable transmission of HIV from an orthopaedic surgeon to a patient in France. Ann Intern Med 1999; 130: 1-6.

11. Mallolas J, Arnedo M, Pumarola T et al. Transmision of HIV-1 from an obstetrician to a patient during a caesarean section. AIDS 2006; 20: 285-287.

12. Goujon C P, Schneider V M, Grofti J et al. Phylogenic analysis indicate an atypical nurse-to-patient transmission of human immunodeficiency virus type 1. J Virol 2000; 74: 2525-2532.

13. Ciesielski C A, Bell D M, Marianos D W. Transmission of HIV from infected healthcare workers to patients. AIDS 1991; 5 Suppl 2: S93-97.

14. Yazdanpanah $Y$, Sisoko D, Egger M, Mouton $Y$ Zwahlen M. Clinical efficacy of antiretroviral combination therapy based on protease inhibitors or non-nucleoside analogue reverse transcriptase inhibitors: Indirect comparison of controlled trials. BMJ 2004; 328: 249 .

15. Jocelyn Elder's foreword to Webber D W. AIDS and the Law (New York Aspen 1997). As reported in HIV AIDS and European Human Rights Law. Bob Watt European Human Rights Law Review 2000.

16. Bailey J R, Sedaghat A R, Kieffer T et al. Residual human immunodeficiency virus type 1 viraemia in some patients on antiretroviral therapy is dominated by a small number of invariant clones rarely found in circulating CD4+ T cells. J Virol 2006; 80: 6441-6457.

17. Sahu G K, Paar D, Frost S D et al. Low-level plasma HIVs in patients on prolonged suppressive highly active antiretroviral therapy are produced mostly by cells other than CD4 T Cells. J Med Virol 2008; 81: 9-15 (Epub ahead of print).

18. Quinn T C, Wawer M J, Sewankambo N et al. Viral Load and heterosexual transmission of human immunodefficiency virus type1 Rakai Project study group. N Engl J Med 2000; 342: 921-929.

19. Centers for Disease Control and Prevention. Investigation of patients treated by and HIVinfected cardiothoracic surgeon - Israel 2007. MMWR Morb Mortal Wkly Rep 2009: 57: 1413-1415.

20. Vernazza P, Hirschel B, Bernasconi E, Flepp M. Les personnes séropositives ne souffrant d'aucune autre MST et suivant un traitment antirétroviral efficace ne transmettent pas le VIH par voie sexuelle. Bull Med Suisses 2008; 89: 165-169.

21. Beijing Declaration 2009. The Mouth and AIDS The Global Challenge. April 2009 Beijing.

22. HIV positive dentists permitted to practice in Europe. Br Dent J 2009; 206: 119.

23. Hancocks S. Blood-borne one year on. Br DentJ 2007; 203: 439.

24. Croser D. Time heals everything. Br Dent J 2010; 209: 589.

25. GDC Standards Committee Meeting January 27 2010 Enclosure C Dental Professionals with Human Immunodefficiency Virus (HIV) (Jenny Watts).

26. Robert L M, Chamberland M E, Cleveland J L et al. Investigations of patients of healthcare workers infected with HIV: The Centres for Disease Control and Prevention Database. Ann Intern Med 1995; 122: 653-657.

27. Irwin D J, Millership S. Description of an HIV patient notification exercise in Essex involving a dental healthcare worker. Commun Dis Public Health 2002 5: 276-281.

28. Scully C, Greenspan J S. Human Immunodeficiency Virus (HIV) in dentistry. J Dent Res 2006; 85: 794-800.

29. Department of Health Publication. HIV Infected Health Care Workers: Guidance on Management and Patient Notification. July 2005.

30. Von Reyn C F, Gilbert T T, Shaw F E, Parsonnet K C, Abramson J E, Smith M G. Absence of HIV transmission from an infected orthopaedic surgeon. A 13-year look-back study. JAMA 1993; 269: 1807-1811.

31. Dickinson G M, Morhart R E, Klimas N G, Bandea C I Laracuente J M, Bisno A L. Absence of HIV transmission from an infected dentist to his patients. An epidemiologic and DNA sequence analysis. JAMA 1993; 269: 1802-1806.

32. Jaffe H W, McCurdy J M, Kalish M L et al. Lack of HIV transmission in the practice of a dentist with AIDS. Ann Intern Med 1994; 121: 855-859.

33. Donnelly M, Duckworth G, Nelson S et al. Are HIV lookbacks worthwhile? Outcome of an exercise to notify patients treated by an HIV infected healthcare worker. Incident Management Teams. Commun Dis Public Health 1999; 2: 126-129.

34. Mason B W, Cartwright J, Sandham S, Witeside C Salmon R. A patient notification exercise following infection control failures in dental surgery. Br Dent J 2008; 205: E8.

35. Department of Health. AIDS/HIV Infected Healthcare Workers: Guidance on the Management of HIV Infected Healthcare Workers and Patient Notification. 2003. 
36. Jagger J, Perry J L. Response to Mallolas et al. Obstetrician-to-patient HIV transmission (correspondence). AIDS 2006; 20: 1785-1786.

37. Yorkshire hospital patients face tests in HIV scare. http://news.bbc.co.uk/1/hi/england/10377839.stm. 22 June 2010.

38. HIV test patients in Yorkshire face 'low risk' http://news.bbc.co.uk/1/hi/england/10388917.stm. 23 June 2010.

39. H (A Healthcare Worker) v Associated Newspapers Ltd, H (A Healthcare Worker) v N (A Health Authority) [2002] EWCA Civ 195.

40. Human Rights Act 1988 Article 8.

41. Human Rights Act 1988 Article 10

42. Hollingsworth T D, Anderson R M, Fraser C. HIV-1 transmission by stage of infection. $J$ Infect Dis 2008: 198: 687-693.

43. Sande M, Volberding PA. The medical management of AIDS. $6^{\text {th }}$ ed. WB Saunders Company, 1999.

44. Muramatsu T, Fukutake K. Diagnosis of HIV infection and AIDS. Nippon Rinsho 2010; 68: 428-432.

45. Centers for Disease Control HIV Testing Basics for Consumers. www.cdc.gov/hiv/topics/testing/ resources/qa/index.htm.

46. Health Protection Agency. HIV in the United Kingdom: 2009 report. www.hpa.org.uk

47. Four in ten UK gay men with HIV are undiagnosed. AVERT UK HIV \& AIDS News. 17 October 2008

48. General Dental Council. Maintaining standards Guidance to Dentists on Professional and Personal Conduct. November s 4.21997.

49. General Dental Council. Standards for dental professionals. May 2005. www.gdc-uk.org.

50. Department of Health. HIV Infected Healthcare Workers: guidance on management and patient notification. DH//HP/GHP3. www.dh.gov/uk/publications

51. Regulation 12 of the Health and Social Care Act 2008 (Regulated Activities) Regulations 2010.

52. Health Technical Memorandum 01-05: decontamination in primary care dental practices. Department of Health - Commissioning Systems Management November 2009.

53. Care Quality Commission: Guidance about compliance. Essential standards of quality and safety. March 2010.

54. Scully C, Moles D R, Fiske J. Infection control: a survey of UK special care dentists and dental care professionals. Prim Dent Care 2007; 14: 40-46.

55. Williams M. The HIV-infected dentist in the United Kingdom - a legal perspective. Br Dent J 2009; 207: 77-81.

56. R V Dica [2004] 3 WLR 213, [2004] 3 All ER 593, R v Konzani [2007] CFLO $1121^{\text {st }}$ March, and others.

57. Cameron E. Criminalization of HIV transmission: poor public health policy. HIV AIDS Policy Law Rev 2009; 14: 63-75.

58. Dodds $C$, Weatherburn $P$, Hickson F, Keogh $P$, Nutland W. Grievous Harm? Use of the Offences Against the Person Act 1861 for sexual transmission of HIV. Briefing paper. $p 2$.

59. Criminal Prosecution Service. Policy for prosecuting cases involving the intentional or reckless sexua transmission of infection. 2008.

60. Miller v Greater Glasgow Health Board [2008] CSOH 2008 WL 2033437.

61. Common law claims based on 'fear of AIDS' L. Camille Herbert Employee Privacy Law Database updated Nov 2008. Part V Medical screening in the Workplace. Ch 11 AIDS and HIV testing V. Common Law Challenges to Employer Use of HIV testing and Employer Discrimination Based on AIDS.

62. Lord Bingham para $1071 \mathrm{R} \vee \mathrm{G}$ [2003] 3 WLR 1060

63. David Perry and Richard Whittam (for the crown) R $\checkmark \mathrm{G}$ [2004] 1 AC 1034.

64. $R \vee$ Caldwell [1982] AC 341

65. M Weaitt Criminal Law and sexual Transmission of HIV: R v Dica (2005). 68 M L R. 121 at p131.
66. S Bronitt Spreading Disease and the Criminal Law [1994] Crim L R. 21 at p 30.

67. Spencer J R. Retrial for reckless infection. $154 \mathrm{NL}$ 76221 May 2004

68. The Times 10 January 2004; Guardian 13 January 2004.

69. Ryan S. Reckless transmission of HIV. Knowledge and culpability. Criminal Law Review 2006.

70. Concern over new testing recommendations AVERT. UK HIV \& AIDS News. September 2008.

71. Gilbart V L, Dougan S, Sinka K, Evans B G. Late diag nosis of HIV infection among individuals with low, unrecognized or unacknowledged risks in England, Wales and Northern Ireland. AIDS Care 2006: 18: 133-139.

72. R v Paulo Matias [2005]

73. Erikson $\mathrm{R}$, Torssander J. Clerics die, doctors survive: a note on death risks among highly educated professionals. Scand J Public Health 2009; 37: 227-231. Epub 2009 Mar 13.

74. Goodman L J. The longevity and mortality of American physicians, 1969-1973. Milbank Mem Fund Q, Health and Society 1975; 53: 353-375.

75. Rimpelä A H, Nurminen M M, Pulkinnen P 0 , Rimpelä M K, Valkonen T. Mortality of doctors: do doctors benefit from their medical knowledge? Lancet 1987; 329: 84-86.

76. Baxter M. Translating health care messages into beneficial behavioural change. Practical Diabetes International 2006; 23: 53-56.

77. Winocour P H. ABCD survey of self-awareness of cardiovascular risk among consultant diabetologists in the UK. Ir Med J 1998; 91: 206-209.

78. O'Connor M, Kelleher C. Do doctors benefit from their profession? - A survey of medical practitioners' health promotion and health safety practices. Ir Med J 1998; 91: 206-209.

79. Kerridge I, Lowe M, McPhee J. Ethics and law for the health professions. $2^{\text {nd }}$ ed. Federation Press, 2005. p 575

80. Guidance for clinical healthcare workers: protection against infection with blood borne viruses. Recommendations of the Expert Advisory Group on AIDS, and the Advisory Group on hepatitis.

81. Sabin C, Smith C, Youle M et al. Deaths in the era of HAART: contribution of late presentation, treatment exposure, resistance and abnormal laboratory markers. AIDS 2005; 20: 67-71.

82. Chadborn T, Baster K, Delpech V et al. No time to wait: how many HIV-infected homosexual men are diagnosed late and consequently die? (England and Wales, 1993-2002). AIDS 2005; 19: 513-520.

83. Chadborn T R, Delpech V C, Sabin C A, Sinka K, Evans B G. The late diagnosis and consequent short-term mortality of HIV-infected heterosexuals (England and Wales, 2000-2004). AIDS 2006; 20: 2371-2379

84. NIMH Multisite HIV prevention Trial. Reducing HIV sexual risk behaviour. Science 1998; 280: 1889-1894.

85. Kamb M L, Fishbein M, Douglas JM Jr et al. Efficacy of risk-reduction counselling to prevent human immunodeficiency virus and sexually transmitted diseases: a randomized controlled trial. Project RESPECT Study Group. JAMA 1998; 280: 1161-1167.

86. Krentz $H_{1}$ Auld M, Gill M. The high cost of medical care for patients who present late (CD4<200 cells) $\mu \mathrm{L})$ with HIV infection. HIV Med 2004; 5: 93-38.

87. Yazdanpanah Y, Goldie S, Losina E et al. Lifetime cost of HIV care in France during the era of highly active antiretroviral therapy. Antivir Ther 2002 7:257-266

88. Crowe S, Hoy J, Mills J (eds). Management of the HIV-infected patient. Cambridge University Press, 1996.

89. Sullivan A K, Curtis H, Sabin C A. Johnson M A.
Newly diagnosed HIV infections: review in UK and Ireland. BMJ 2005; 330: 1301-1302. Epub 2005 May 13.

90. Delpierrre C, Cuzin L, Lauwers-Cances V, Marchou $B$, Lang T. High risk groups for late HIV diagnosis of HIV infections: a need for rethinking testing policy in the general population. AIDS Patient Care STDS 2006; 20: 238-2347

91. Delpierrre C, Dray-spira R, Cuzin L et al. Correlates of late diagnosis in France. Implications for testing policy. Int J STD AIDS 2007; 18: 312-317.

92. Lattimore S, Yin Z, Logan L et al. Situation of HIV infections and STIs in the United Kingdom in 2007. Euro Surveill 2008; 13: pii19059.

93. Delpierre C, Cuzin L, Lert F. Routine testing to reduce late HIV diagnosis in France. BMJ 2007; 334: 1354-1356.

94. Hamill M, Burgoine K, Farrell F et al. Time to move towards opt-out testing for HIV in the UK. BMJ 2007: 334: 1352-1354.

95. British HIV Association (BHIVA). UK National Guidelines for HIV Testing 2008. http://www.bhiva. org/HIVTesting2008.aspx

96. Dodds C, Weatherburn P. Reducing the length of time between HIV infection and diagnosis. BMJ 2007; 334: 1329-1330.

97. Concern over new HIV testing recommendations. AVERT UK HIV and AIDS News 22 September 2008

98. Possible transmission of human immunodeficiency virus to a patient during an invasive dental procedure. MMWR Morb Mortal Wkly Rep 1990; 39: 489-493.

99. The Kimberley Bergalis Patient and Health Providers' Protection Act 1991. Introduced by Senator William Dannemyer.

100. Recommendations for preventing transmission of human immunodeficiency virus and hepatitis B virus to patients during exposure-prone invasive procedures. MMWR Recomm Rep 1991; 40: 1-9.

101. Glantz L, Mariner W K, Annas G. Risky business: setting public health policy for HIV-infected healthcare professionals. Milbank 0 1992; 70: 43-79.

102. Health clearance for tuberculosis, hepatitis $B$, hepatitis $C$ and HIV: new healthcare workers. March 2007. http://www.dh.gov.uk/ en/Publicationsandstatistics/Publications/ PublicationsPolicyAndGuidance/DH_073132

103. Salkeld L R, McGeehan S J, Chaudhuri E, Kerslake I M. HIV testing of junior doctors: exploring their experiences, perspectives and accounts. J Med Ethics 2009; 35: 402-406.

104. Salkeld L, McGeehan S. HIV testing of health care workers in England - a flawed policy. J Health Serv Res Policy 2010; 15 Suppl 2: 62-67. Epub Feb 10.

105. United Kingdom Advisory Panel for Healthcare Workers Infected with Bloodborne Viruses. Second Report 1 April 2004 to 31 December 2006.

106. Department of Health/Health Protection Division/ General Health Protection. Hepatitis B Infected Healthcare Workers and Antiviral Therapy. March 2007

107. Department of Health. Hepatitis C Infected Health Care Workers. HSC 2002/010.

108. Public Health (Infectious Diseases) Regulations 1988 SI 1988/1546

109. J K Mason, G T Laurie Mason and McCall Smith's law and medical ethics. $7^{\text {th }}$ ed. Oxford University Press, 2006. p 32-33.

110. Orr A. The legal implications of AIDS and HIV infection. In Almond B. AIDS: a moral issue. The ethical, legal and social aspects. Macmillan Press Ltd, 1990. p 133

111. UN General Assembly. Scaling up HIV prevention, treatment and support: note by the secretary general. Geneva: United Nations, 2006. http://data. unaids.org/pub/InformationNote/2006/20060324 HLM GA A60737 en.pdf 